\title{
Detecção de Brucella spp. em leite bovino não pasteurizado através da Reação de Cadeia pela Polimerase (PCR)
}

\author{
Detection of Brucella spp. in unpasteurized cow milk by polymerase \\ chain reaction ( $P C R$ ) \\ Carolina Lechinski de Paula', Mateus de Souza Ribeiro Mioni', Camila Michele Appolinário', \\ Edson Ryuiti Katayama', Susan Dora Allendorf', Jane Megid ${ }^{1 *}$
}

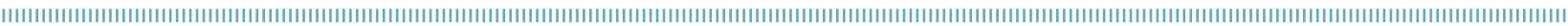

RESUMO: A brucelose é uma importante zoonose causada por bactérias do gênero Brucella. O homem é infectado pelo contato com as secreçóes reprodutivas como placenta, lóquios placentários, sêmen e secreçôes penianas de animais infectados ou pelo consumo de leite e derivados não pasteurizados. Com o objetivo de pesquisar a presença da bactéria no leite, foram avaliadas, através da técnica da reação em cadeia da polimerase (PCR), 30 amostras de leite cru comercializadas clandestinamente na regiâo de Botucatu, São Paulo, bem como 50 amostras de leite entregues em laticínio, previamente à pasteurizaçáo. Das 80 amostras analisadas pela técnica de PCR, 10 $(12,5 \%)$ foram positivas e $70(87,5 \%)$ negativas. Dentre as amostras positivas, 5 amostras (16,6\%) eram provenientes de comerciantes ilegais e outras 5 amostras (10\%) foram obtidas no laticínio. A positividade para Brucella spp. demonstra que o patógeno se encontra presente de forma importante na região de Botucatu, São Paulo, e que o risco associado à saúde pública devido à comercialização de produtos clandestinos sem prévia pasteurização é real.

PALAVRAS-CHAVE: brucelose; Brucella abortus; leite; PCR.
ABSTRACT: Brucellosis is a zoonosis caused by bacteria of the genus Brucella. Man infection occurs through contact with reproductive secretions as placenta and its lochia, semen and penile secretion of infected animals or by consuming unpasteurized milk and dairy products. With the objective of investigating the presence of bacteria in milk, 30 samples of raw milk sold illegally in the region of Botucatu, São Paulo, Brazil, as well as 50 samples of milk delivered to a dairy industry previously to its pasteurization were evaluated by the polymerase chain reaction (PCR) technique. Of the 80 samples analyzed, 10 samples $(12.5 \%)$ were positive and $70(87.5 \%)$ were negative. Among the positive samples, $5(16.6 \%)$ were from illegal traders and other $5(10 \%)$ were obtained from the dairy industry. Brucella spp. positivity shows that the pathogen is representatively present in Botucatu, São Paulo, Brazil, and the risk associated to public health due to the commercialization of illegal products without pasteurization is real.

KEYWORDS: brucellosis; Brucella abortus; milk; PCR.

'Faculdade de Medicina Veterinária e Zootecnia; Departamento de Higiene Veterinária e Saúde Pública; Universidade Estadual Paulista “Júlio de Mesquita Filho” (UNESP) - Botucatu (SP), Brasil.

*Autor correspondente: jane@fmvz.unesp.br

Recebido em: 10/04/2013. Aceito em: 03/10/2014. 
A brucelose é uma enfermidade infectocontagiosa, de caráter zoonótico e ampla distribuição mundial. A enfermidade acomete uma ampla variedade de espécies de mamíferos terrestres e marinhos, incluindo o homem, considerado um hospedeiro acidental, causando enfermidade também conhecida como febre ondulante, febre do Mediterrâneo ou febre de Malta. Nos seres humanos a brucelose é classificada como enfermidade ocupacional para pessoas que lidam diretamente com animais ou com seus produtos, como por exemplo fazendeiros, médicos veterinários, magarefes, açougueiros e trabalhadores da indústria de laticínios.

A doença, nos animais domésticos, é causada por bactérias do gênero Brucella, sendo identificadas como Brucella melitensis, B. abortus, B. suis, B. ovis e B. canis, destacando-se a Brucella abortus, que acomete principalmente os bovinos, podendo também causar doença no homem.

A brucelose bovina é a mais prevalente no Brasil, sendo considerada endêmica em algumas regiôes. Segundo os dados mais recentes do Ministério da Agricultura, Pecuária e Abastecimento, um levantamento epidemiológico realizado entre os anos de 2001 e 2004 demonstrou que a prevalência de brucelose em $82 \%$ do efetivo bovino no Brasil variou entre 0,06 e $10,2 \%$. A ocorrência da doença nos rebanhos bovinos causa grandes prejuízos econômicos relacionados à queda de produçáo e a problemas reprodutivos.

A infecção por $B$. abortus leva à ocorrência de endometrites, retenção placentária, abortamentos, redução na vitalidade dos bezerros por morte precoce ou subdesenvolvimento (30\%), diminuição da lactação (20\%), esterilidade das fêmeas infectadas (30\%), redução do peso dos animais em torno de $15 \%$, além do aumento do intervalo entre partos, que passa de 12 meses (considerado normal e ideal) para até 20 meses. Em estudo publicado em 2013 sobre as perdas econômicas geradas por rebanhos bovinos de corte e leite acometidos por brucelose, estimou-se prejuízo na ordem de 440 milhôes de dólares. Não podendo ser desconsideradas as perdas indiretas relacionadas à doença nos seres humanos, como gastos médicos e perda de produtividade/afastamento de funcionários.

Os animais infectados permanecem portadores por toda a vida, caracterizando a fase crônica da doença. Nessa fase, os animais são assintomáticos ou apresentam poucos sinais e a bactéria persiste em linfonodos e glândulas mamárias. Durante a gestação, a brucela migra para o útero, local pelo qual possui grande tropismo, sendo eliminada pelo leite, urina, descargas vaginais, produtos do abortamento e lóquios placentários.

O homem se infecta naturalmente pelo contato com produtos abortados, secreçóes vaginais, lóquios placentários e outras secreções contaminadas, além do consumo de leite cru ou derivados não pasteurizados, sendo esta última considerada a forma de contaminação principal dos seres humanos.

No homem, a doença afeta vários sistemas, produzindo uma grande variedade de sintomas, no entanto, a forma assintomática também pode ocorrer. Clinicamente, a brucelose humana se manifesta por febre aguda, acompanhada de mal estar, anorexia e prostraçáo, podendo persistir e progredir para a cronicidade, com severas complicaçóes osteomusculares, neurológicas e cardíacas.

A pasteurização do leite, que visa eliminar patógenos em potencial, é uma prática fundamental para garantir a saúde dos consumidores e garantir a qualidade dos produtos alimentícios, o que também possibilita o controle da brucelose humana, por eliminar as brucelas do leite. Apesar da obrigatoriedade da pasteurizaçáo no Brasil, ainda se observa a venda de leite in natura de forma clandestina, em diversas regiốes brasileiras.

O diagnóstico sorológico da brucelose preconizado pelo Programa Nacional de Controle e Erradicaçáo da Brucelose e da Tuberculose (PNCEBT), programa este que foi implementado pelo governo federal no ano de 2002 e tem por objetivo eliminar progressivamente a doença no país, determinou o teste do antígeno acidificado tamponado (AAT) como um teste de rotina, e no caso de positividade, pode-se realizar a técnica do 2-Mercaptoetanol, composta por duas provas, a Soro aglutinaçáo lenta (SAL) e a prova do 2-mercaptoetanol, lidas em paralelo como prova confirmatória da AAT. Em rebanhos leiteiros de estabelecimentos atestados como livres de brucelose, o monitoramento pode ser feito através do teste do anel em leite (TAL) empregado em amostras coletadas de tambores ou tanques de expansão, sendo necessária a realizaçâo de testes sorológicos individuais em caso de positividade. Embora o TAL seja considerado um eficiente e prático teste de vigilância epidemiológica dos rebanhos, ele pode resultar positivo em amostras de leite de animais que apresentem outras infecçóes que não por brucela ou também amostras de leite de rebanho vacinados com a vacina B19, que é a preconizada pelo PNCEBT. A confirmação do diagnóstico depende dos testes sorológicos individuais e/ou da detecçáo da brucela nos animais ou em seus subprodutos, por meio da utilização de ferramentas diagnósticas como a reação em cadeia da polimerase (PCR). A tecnologia de PCR tem sido aplicada para detecção de contaminação por Brucella spp. em alimentos, principalmente leite e queijos frescos, mas também em tecidos e secreçóes animais. A técnica provou ser altamente sensível e possível de ser empregada em grandes volumes de amostras.

Considerando o destacado papel que o leite assume na alimentação humana e a sua importância como um dos fatores de risco associados à transmissão da doença, este trabalho objetivou avaliar a presença de Brucella spp. em amostras de leite vendido clandestinamente na cidade de Botucatu, Sáo Paulo, bem como amostras de leite entregues em laticínio previamente à sua pasteurização.

Para isso, foram coletadas 30 amostras de leite cru vendido por carroceiros, na cidade de Botucatu, São Paulo, bem como 50 amostras de leite, previamente à sua pasteurização, entregues em um laticínio da regiáo. As amostras foram coletadas 
em tubos estéreis de $20 \mathrm{~mL}$ e acondicionadas sob refrigeração até a chegada ao laboratório.

Após a coleta, $10 \mathrm{~mL}$ de cada amostra foram separados e acrescidas de $1 \mathrm{~mL}$ de formol a $1 \%$ em tubos do tipo Falcon para realização do TAL, sendo esses também mantidos sob refrigeração até a realização do teste. O TAL foi realizado segundo o protocolo descrito no manual técnico do PNCEBT.

Para a realizaçáo da técnica de PCR, as amostras foram aliquotadas em microtubos de $2 \mathrm{~mL}$ e congeladas a $-20^{\circ} \mathrm{C}$. A sensibilidade analítica da extração do DNA realizada com kit comercial Spin Tissue Mini Kit Invisorb ${ }^{\circledR}$ foi previamente avaliada por meio da contaminaçấo de leite esterilizado com cinco diluiçôes conhecidas $\left(10^{-1}, 10^{-2}, 10^{-3}\right.$, $\left.10^{-4}, 10^{-5}\right)$ de Brucella abortus extraída de meio de cultura. $O$ protocolo de extraçáo escolhido demonstrou sensibilidade até a diluição $10^{-2}$. Embora outros autores tenham relatado uma sensibilidade maior com outros métodos de extração, a utilização do kit comercial foi escolhida devido à maior facilidade de execução e menor chance de contaminação cruzada entre as amostras testadas.

Os primers utilizados foram previamente descritos por BaILY et al. (1992) e o protocolo de amplificaçáo foi realizado de acordo com Cortez (2001). A reação de PCR ocorreu sob as seguintes condiçôes: desnaturação inicial a $94^{\circ} \mathrm{C}$ por 5 minutos, 40 ciclos de $94^{\circ} \mathrm{C}$ por 60 segundos, $60^{\circ} \mathrm{C}$ por 60 segundos, $72^{\circ} \mathrm{C}$ por 60 segundos e ciclo de extensão final a

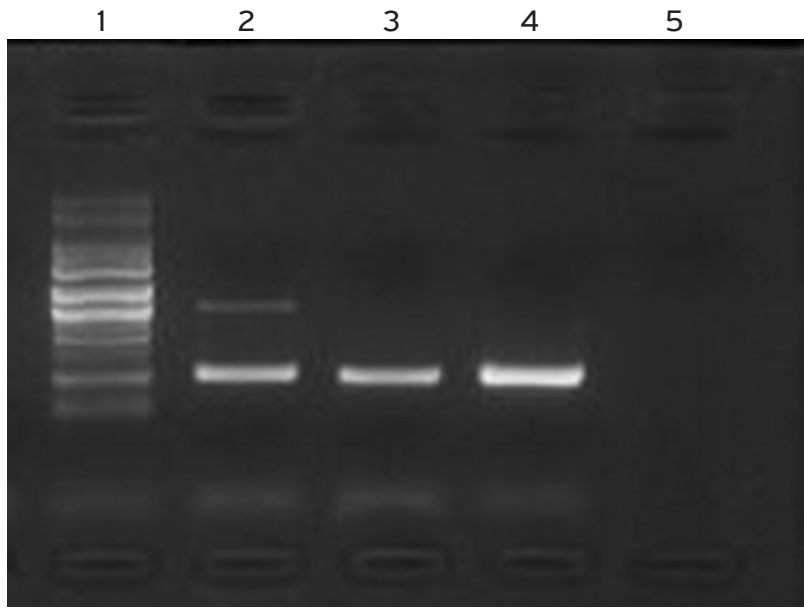

Figura 1. Eletroforese em gel de agarose a $2 \%$ demonstrando o produto amplificado da reação em cadeia da polimerase, utilizando primers especificos para Brucella spp. com bandas de 223 bp. Coluna 1: marcador com peso molecular de 100 bp; Coluna 2: controle positivo; Colunas 3 e 4: amostras positivas; Coluna 5: controle negativo. $72^{\circ} \mathrm{C}$ por 10 minutos. Foi utilizado como controle negativo da reação água ultrapura e como controle positivo leite previamente contaminado pela adiçấo de $20 \mu \mathrm{L}$ de solução salina contendo $B$. abortus na diluição $10^{-2}$ baseada na escala 1 de MacFarland, em $200 \mu \mathrm{L}$ de leite. A visualização do produto amplificado foi realizada com eletroforese em gel de agarose a $2 \%$ contendo $0,5 \mathrm{mg} / \mathrm{mL}$ de brometo de etídio. Foi considerado positivo a presença de fragmentos equivalentes a 223 pares de bases (pb) (Fig. 1)

A análise estatística dos resultados obtidos nos dois grupos (carroceiros e laticínio) foi realizada pelo emprego do teste $\mathrm{t}$ de Student, considerando como significante $\mathrm{p}<0,05$; utilizando como ferramenta estatística o software Graphpad Stat ${ }^{\circledR}$.

O TAL e a técnica de PCR foram realizadas em todas as amostras coletadas $(n=80)$. Das amostras coletadas de carroceiros, observou-se $30 \%$ de positividade no TAL (9 amostras) e 16,6\% de positividade na PCR (5 amostras). No leite coletado no laticínio, 13 amostras (26\%) foram positivas no TAL e 5 amostras (10\%) foram positivas na PCR (Tabela 1). Do total das 80 amostras analisadas, foram obtidos no TAL 22 resultados positivos $(46,25 \%)$ e 43 negativos (53,75\%). Pela técnica da PCR, 10 amostras $(12,5 \%)$ resultaram positivas e 70 negativas $(87,5 \%)$, sendo essas 10 amostras também positivas no TAL, caracterizando a situação de animal infectado com eliminação de Brucella spp. pelo leite. Não foi observada diferença estatística $(\mathrm{p}=0,3891)$ no percentual de positividade na PCR realizada nas amostras de leite entregues em laticínio e naquelas comercializadas clandestinamente.

A presença de Brucella spp. no leite representa uma das principais formas de transmissão da brucelose. A detecção de bactérias tanto no leite vendido clandestinamente como no fornecido para o laticínio demonstra a importância da pasteurização realizada nos laticínios como mecanismo de proteção à saúde humana e reforça o risco do consumo do leite sem qualquer tipo de tratamento térmico. Neste sentido, a venda de leite in natura de forma clandestina constitui um risco ainda maior à saúde pública, uma vez que este, na maioria das vezes, é consumido fresco ou utilizado na produçáo de queijo frescal.

A TAL associado à técnica de PCR demonstrou ser um bom método diagnóstico para presença de Brucella spp. no leite. Apesar da implantação do PNCEBT há mais de uma década, animais brucélicos ainda são encontrados e seu leite é comercializado de maneira clandestina ou não, tornando-se indispensável seu tratamento térmico antes do consumo.

Tabela 1. Relação entre a positividade obtida no teste do anel e na reação em cadeia da polimerase nas amostras de leite coletadas de carroceiros e no laticínio.

\begin{tabular}{lcccc} 
Amostras & Teste do anel & $\begin{array}{c}\text { Reação em cadeia } \\
\text { da polimerase }\end{array}$ & $\begin{array}{c}\text { Porcentagem no teste } \\
\text { do anel }\end{array}$ & $\begin{array}{c}\text { Porcentagem na reação } \\
\text { em cadeia da polimerase }\end{array}$ \\
Carroceiros & $9 / 30$ & $5 / 30$ & 30 & 16,6 \\
\hline Laticínio & $13 / 50$ & $5 / 50$ & 26 & 10
\end{tabular}


Agradecemos ao Programa Institucional de Bolsas de Iniciação (PIBIC) e ao Conselho Nacional de Desenvolvimento Científico e Tecnológico ( $\mathrm{CNPq}$ ) pela concessão de bolsa de Iniciação Científica a Carolina Lechinski de Paula. Agradecemos também ao Laboratório de
Biologia Molecular do Departamento de Higiene Veterinária e Saúde Pública, da Faculdade de Medicina Veterinária e Zootecnia da Universidade Estadual Paulista "Júlio de Mesquita Filho" (UNESP) de Botucatu, São Paulo, pelo auxílio na prática deste projeto.

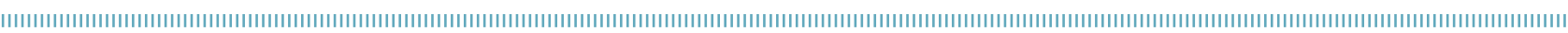

\section{REFERÊNCIAS}

BAILY, G.G.; KRAHN, J.B.; DRASAR, B.S.; STOKER, N.G. Detection of Brucella melitensis and Brucella abortus by DNA amplification. The Journal of Tropical Medicine and Hygiene. v.95, n.4, p.271-275, 1992.

BADINI K.B.; NADER FILHO, A.; AMARAL, L.A.; GERMANO, P.M.L. Risco à saúde representado pelo consumo de leite cru comercializado clandestinamente. Revista de Saúde Pública, v.30, n.6, p. 549-552, 1996.

BARBOSA, S.M. Isolamento, tipificação e genotipagem de Brucella abortus isoladas de bovinos no Brasil. 2009. 77f. 2009. Tese (Doutorado) - Escola de Veterinária, Universidade Federal de Minas Gerais, Belo Horizonte, 2009.

BENNETT J.C.; PLUM F. (Eds.). Tratado de Medicina Interna. Volume 2. $2^{\mathrm{a}}$ ed. Rio de Janeiro: Guanabara Koogan, 1997. 2647p.

BRASIL. Ministério da Agricultura, Pecuária e Abastecimento. Instrução Normativa n 51 , de 18 de setembro de 2002. Brasília: MAPA, 2002.

BRASIL. Ministério da Agricultura, Pecuária e Abastecimento. Secretaria Nacional de Defesa Agropecuária. Regulamento Técnico do Programa Nacional de Controle e Erradicação da Brucelose e Tuberculose Animal. Brasília: MAPA, 2006.

BRASIL, Ministério da Agricultura, Pecuária e Abastecimento. Secretaria de Defesa Agropecuária. Departamento de Saúde Animal. Manual de Legislação: programas nacionais de saúde animal do Brasil. Brasília: MAPA, 2009. 440p.

BRICKER, B.J. PCR as a diagnostic tool for brucellosis. Veterinary Microbiology, v.90, n. 1-4, p.435-446, 2002.

CHAHOTA, R. Brucellosis outbreak in an organized dairy farm involving cows and in contact human beings, in Himachal Pradesh, India. Veterinary Archives, v.73, p.95-102, 2003.

CHIELLE, L.L.; WEIBLEN, R.; MOREIRA, W.S.; FLÔRES M.L. Especificidade da prova do anel de leite (PAL) para o diagnóstico da brucelose bovina na bacia leiteira do município de Santa Maria, RS, Brasil. Revista do Centro de Ciências Rurais, v. 19, n.4, p.351-358, 1989.

CORBEL, M.J. Brucellosis in Humans and Animals. Geneva: World Health Organization, 2006.

CORTEZ, A. Detecção de DNA de Brucella spp em amostras clínicas de abortos bovinos pela reação em cadeia pela polimerase. 34f. 2001. Dissertação (Mestrado em Medicina Veterinaria) Faculdade de Medicina Veterinária e Zootecnia, Universidade de São Paulo, São Paulo, 2001.

FELLOWS, P.J. Food Processing Technology: principles and practice. New York: Ellis Horwood, 1998. 505p.

GOMES, M.J.P. 2007. Brucella spp. Microbiologia Clínica. Porto Alegre: Lab Vet, 2007.

JARDIM, G.C.; PIRES, P.P.; MATHIAS, L.A.; RIBEIRO, O.C.; KUCHEMBUCK, M.R.G. Diagnóstico sorológico da Brucelose bovina em animais adultos vacinados com dose reduzida da cepa 19 de Brucella abortus. Pesquisa Veteinária Brasileira, v.26, n.3, p.177-182, 2006.

LANGONI, H.; ICHIHARA, S.M.; SILVA, A.V.; PARDO, R.B.; TONIN, F.B.; MENDONÇA, L.J.P.; MACHADO, J.A.D. Isolation of Brucella spp from milk of brucellosis positive cows in São Paulo and Minas Gerais states. Brazilian Journal of Veterinary Research and Animal Science, v.37, n.6, p.444-448, 2000.

LEAL-KLEVEZA, D.S.; MARTÍNEZ-VÁZQUEZ, I.O.; LÓPEZMERINO, A.; MARTÍNEZ-SORIANO, J.P. Single-step PCR for detection of Brucella spp. from blood and milk of infected animals. Journal of Clinical Microbiology, v.33, n. 12, p.30873090, 1995.

LUCAS, A. Simulação de impacto econômico da brucelose bovina em rebanhos produtores de leite das regiões Centro Oeste, Sudeste e Sul do Brasil. 2006. Tese (Doutorado) Faculdade de Medicina Veterinária e Zootecnia, Universidade de São Paulo, São Paulo, 2006.

O 'LEARY, S.; SHEAHAN, M.; SWEENEY, T. Brucella abortus detection by PCR assay in blood, milk and lymph tissue of serologically positive cows. Research in Veterinary Science, v.81, n.2, p. 170-176, 2006.

PESSEGUEIRO, P.; BARATA, C.; CORREIA, J.; Brucelose: uma revisão sistematizada. Medicina Interna, v. 10, n.2, p.91-99, 2003.

POESTER, F.P.; GONÇALVES, V.S.P.; LAGE, A.P. Brucellosis in Brazil. Microbiology, v.90, p.55-62, 2002.

PEROTTO, D.; ABRAHÃO, J.J.S.; KROETZ, I.A. Intervalo de partos de fêmeas bovinas Nelore, Guzerá x Nelore, Red Angus x Nelore, Marchigiana x Nelore e Simental x Nelore. Revista Brasileira de Zootecnia, v.35, n.3, p.733-741, 2006. 
ROMERO, C.; PARDO, M.; GRILLO, M.J.; DIAZ, R.; BLASCO, J.M.; LOPEZGOÑI, I. Evaluation of PCR and indirect enzyme-linked immunosorbent assay on milk samples for diagnosis of brucellosis in dairy cattle. Journal of Clinical Microbiology, v.33, n. 12, p.3198-3200, 1995.

RICHTZENHAIN, L.J.; CORTEZ, A.; HEINEMANN, M.B.; SOARES R.M.; SAKAMOTO, S.M.; VASCONCELLOS, S.A.; HIGA, Z.M.; SCARCELLI, E.; GENOVEZ, M.E. A multiplex PCR for the detection of Brucella spp. and Leptospira spp. DNA from aborted bovine fetuses. Veterinary Microbiology, v.87, n.2, p.139-147, 2002.
SANTOS, R.L.; MARTINS, T.M.; BORGES, A.M.; PAIXÃO, T.A. Economic losses due to bovine brucellosis in Brazil. Pesquisa Veterinária Brasileira, v.33, n.6, p.759-764, 2013.

SCHEIN, F.B.; SANTOS, M.D.; SIQUEIRA, A.A.F.; MOSQUETTE, R.; FREITAS, S.H.; CASTRO, R.S.; SIMÕES, R.S.; CAMARGO, L.M. Prevalência de brucelose em bovinos de leite e fatores de risco associados à transmissão em seres humanos. Arquivos do Instituto Biológico, v.71, supl.1, p.1-749, 2004. 